\title{
Effect of Species Composition on Polycyclic Aromatic Hydrocarbon (PAH) Accumulation in Urban Forest Soils of Krakow
}

\author{
Jarosław Lasota $•$ Stanisław Kyszczarz • Piotr Kempf • \\ Marta Kempf • Ewa Błońska
}

Received: 1 December 2020 / Accepted: 4 February 2021 /Published online: 12 February 2021

(C) The Author(s) 2021

\begin{abstract}
Polycyclic aromatic hydrocarbons (PAHs) are among the most hazardous organic pollutants due to their toxic, carcinogenic, mutagenic properties, wide distribution, recalcitrance and stability in the environment. The study objective is to determine the impact of the species composition of tree stands on PAH accumulation in urban forest soils of Krakow. The study compared the impact of deciduous and coniferous species on similar soils on PAH biodegradation. Basic physicochemical properties, activity of enzymes involved in the nutrient cycle and PAH content were measured in soil samples. Our study shows lower accumulation of PAHs in soils with deciduous tree stands, which are characterized by higher $\mathrm{pH}$ and higher biochemical activity expressed by enzymatic activity. There is statistically significant difference in the enzymatic activity in the soils of deciduous tree stands, which results in differences in PAH accumulation. Among the studied deciduous species, soils with Norway maple and locust were characterized by highest enzymatic activity. At the same time, soils under these species were characterized by the lowest PAH accumulation. Among the coniferous species, highest PAH accumulation was observed
\end{abstract}

J. Lasota $(\bowtie) \cdot$ S. Łyszczarz $\cdot$ M. Kempf $\cdot$ E. Błońska Department of Ecology and Silviculture, Faculty of Forestry, University of Agriculture in Krakow, 29 Listopada 46 Str, 31-425 Kraków, Poland

e-mail: rllasota@cyf-kr.edu.pl

P. Kempf

Kraków Municipal Greenspace Authority, Reymonta 20 Str, 30-059 Kraków, Poland under pine and spruce, where low enzymatic activity was observed at the same time.

Keywords Acidity $\cdot$ Biochemical activity $\cdot$ Deciduous species $\cdot$ Coniferous species $\cdot$ Krakow $\cdot$ Soil organic matter

\section{Introduction}

Increase in the soil environment pollution with persistent organic pollutants has been observed for many years. This group includes polycyclic aromatic hydrocarbons (PAHs). PAHs are generated during the processes of hydrolysis and incomplete combustion of organic matter; they can be created naturally or as a result of human activity (Srogi 2007). Polycyclic aromatic hydrocarbons are substances with carcinogenic and mutagenic potential (Błaszczyk et al. 2017). The effect of PAHs on soil results in changes of the physicochemical properties of the solution and toxicity towards cells and tissues of living organisms (Oleszczuk 2007; Zhan et al. 2010). PAHs have ring structure meaning that they are resistant to biodegradation, and carcinogenic index increases with the growth of the number of aromatic rings (Marston et al. 2001). The biological decomposition of organic pollutants such as PAHs by microorganisms is one of the most significant and efficient means of removing these compounds from the environment. PAHs in soils are subject to 
microbiological transformations with the participation of fungi, bacteria and actinomycetes, as well as sorption, leaching, reactions with other compounds and photodegradation (Wilcke and Amelung 2000). The biodegradation consists in the decomposition of exogenous substances present in the environment with the participation of metabolic pathways of living organisms, mainly bacteria, fungi and plants (Gan et al. 2009). The degradation process depends on the composition and activity of microorganisms, $\mathrm{pH}$, access to oxygen or nutrient content (Mrozik et al. 2003). One of the most important parameters affecting the amount of PAHs in soil is the content of organic matter, which is characterized by high sorption capacities (Błońska et al. 2016a; Lasota and Błońska 2018). Organic matter is the binding factor for PAHs in soil environment and it is responsible for the ageing of PAHs, restricting their diffusion or release to soil in the solution (Luo et al. 2012; Wang et al. 2012). Soil microorganisms constitute the main motor for the biochemical cycle, affecting the decomposition of organic compounds (Deng et al. 2016). The quality of the litter directly affects microbial decomposer communities, which are related to the decomposition of litter by the secretion of extracellular enzymes (Graça and Poquet 2014). Soil properties can be affected by the species composition of vegetation, i.e. amount and quality of soil organic matter, acidification or the amount of nutrients (Błońska et al. 2016b; Błońska et al. 2017). Coniferous and deciduous species of trees affect soil properties differently via the plant litter fall and root systems (Błońska et al. 2021). Coniferous species lead to $\mathrm{pH}$ reduction, and as a consequence to reduce the enzymatic activity of soils (Błońska et al. 2016a). Deciduous species contain more easily decomposed components than coniferous species. It is known that changes in soil properties are associated with changes in its microbial structure. Communities of soil microorganisms impact on the function of soil, because they participate in the nutrient cycle and carbon storage (Xue et al. 2018). The belowground microbial communities are acting as regional drivers of the aboveground biotic communities such as plant species diversity and productivity (Van Der Heijden et al. 2008). Measurements of the extracellular enzymes activity involved in the nutrient cycles originating from organic compounds provide information about the biogeochemical circulation that occurs in soil (Yavitt et al. 2004). The availability of $\mathrm{C}$ and nutrients in the soil, especially in the rhizosphere, strongly affects the microbial biomass and catalytic efficiency of enzymes (Loeppmann et al. 2016).

The study objective is to determine the effect of tree stand species composition on PAH accumulation in urban forest soils of Krakow. In the study, influence of deciduous and coniferous species growing on similar soils was compared. We tested the following research hypotheses: (1) by providing more easily decomposable organic matter, deciduous species stimulate biochemical activity of soils, which results in lower PAH content; (2) coniferous species reduce soil $\mathrm{pH}$ and increase soil acidity, which results in lower enzymatic activity and reduces PAH biodegradation.

\section{Materials and Methods}

\subsection{Study Area and Soil Sampling}

The study was conducted in the urban forest in the Kraków (50 $03^{\prime} 41^{\prime \prime} \mathrm{N} ; 19^{\circ} 56^{\prime} 18^{\prime \prime}$ E) (Fig. 1). The research covered Reduta Forest, Zesławice Forest, Wolski Forest and Tyniec Forest. The area covered by the study is occupied by Luvisols (Skiba and Drewnik 2013). The soils studied were characterized by a similar moisture. The average temperature in the study area was $8.5^{\circ} \mathrm{C}$ and the average annual precipitation was about $715 \mathrm{~mm}$. Kraków is the second largest town in Poland with an area $327 \mathrm{~km}^{2}$. Kraków has become one of the most polluted cities in Europe, in recent years (Wilczyńska-Michalik and Michalik 2017). The main contaminations are $\mathrm{SO}_{2}, \mathrm{NO}_{x}, \mathrm{CO}$ and benzo(a)pyrene. The dense public transport, private car traffic, close proximity to the mining region of Upper Silesia, Balice airport and long-distance road traffic were reasons for soil pollution in Krakow (Ciarkowska et al. 2019).

The study was conducted in 2020. Deciduous and coniferous stands were selected for further analysis in each of the four Kakow urban forests covered by the study. The study covered Norway spruce (Picea abies) and Norway maple (Acer platanoides) in Reduta Forest, Scots pine (Pinus sylvestris) and English oak (Quercus robur) in the Tyniec Forest, European larch (Larix deciduas) and black locust (Robinia pseudoacacia) in the Zesławice Forest, and Douglas fir (Pseudotsuga menziesii) and European beech (Fagus sylvatica) in 
Fig. 1 Localization of study plots in urban forest of Krakow (green point-Reduta Forest; blue point—Zesławice Forest; yellow point-Wolski Forest; red point-Tyniec Forest)

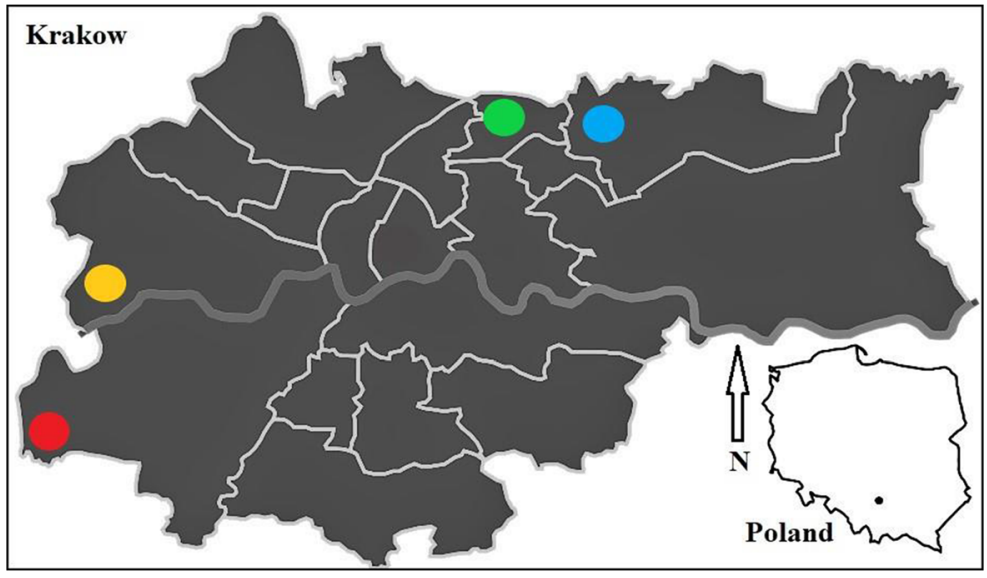

the Wolski Forest. Each variant of study plots was in three repetitions. In total, 24 study plots were investigated (4 urban forest $\times 2$ species $\times 3$ repetitions). Soil samples were collected on each study plot for laboratory analysis. On plots with deciduous species, soil samples were taken from the humus mineral horizon (A). On the other hand, on the plots with coniferous species, soil samples were collected from the organic horizon (Ofh) and humus mineral horizon (A). In the soils of deciduous and coniferous stands, the samples for analysis were collected after removing the litter level.

\subsection{Laboratory analysis}

The texture was determined using laser diffraction (Analysette 22, Fritsch, Idar-Oberstein, Germany). The soil $\mathrm{pH}$ was determined in $\mathrm{H}_{2} \mathrm{O}$ and $\mathrm{KCl}$ using the potentiometric method. $\mathrm{C}$ and $\mathrm{N}$ were measured using an elemental analyser (LECO CNS TrueMac Analyzer Leco, St. Joseph, MI, USA). The cation concentrations and contents of $\mathrm{Cd}, \mathrm{Cr}, \mathrm{Cu}, \mathrm{Ni}, \mathrm{Pb}$ and $\mathrm{Zn}$ were determined by inductively coupled plasma analysis (ICP-OES Thermo iCAP 6500 DUO, Thermo Fisher Scientific, Cambridge, UK). We used the Kappen method to determine the hydrolytic acidity and Sokolow method to determine the exchangeable acidity (Ostrowska et al. 1991). The PAHs were determined in $10 \mathrm{~g}$ of each soil sample, extracted using $70 \mathrm{ml}$ of propan-2-ol. The samples were centrifuged (4500 rpm, 5 $\mathrm{min})$ and the supernatant collected. The supernatants were extracted to the solid phase $(5 \mathrm{ml} / \mathrm{min})$ using solid-phase extraction (CHROMABOND® $\mathrm{CN} / \mathrm{SiOH}$ ). The residue was dissolved in acetonitrile and analysed using highpressure liquid chromatography (HPLC) with a Dionex UltiMate 3000 HPLC system, equipped with a fluorescence detector and a Dionex UltiMate 3000 Column Compartment C18 $5 \mu$ m with a $4.6 \times 100$-mm HPLC column. The mobile phases were water $(\mathrm{A})$ and acetonitrile (B) at a flow rate of $1 \mathrm{ml} / \mathrm{min}$. Based on the standard PAH Calibration Mix (CRM 47940) at a concentration of 10 $\mu \mathrm{g} / \mathrm{ml}$, calibration solutions at different concentrations (i.e. $0.1,0.2,0.5,1$ and $2 \mu \mathrm{g} / \mathrm{ml}$ ) were prepared. Each prepared solution was placed into the chromatography column, the chromatograms obtained being used to produce a calibration curve. The soil samples were then analysed in triplicate. After every ninth analysis, a control sample (a calibration solution with a concentration of $0.1 \mu \mathrm{g} / \mathrm{ml}$ ) was injected. Acenapthene (Ace), fluoren (Flu), phenanthrene (Phe), antracen (Ant), fluoranthene (Flt), pyrene (Pyr), benzo(a)anthracene (BaA), chrysene (Chr), benzo $(k)$ fluoranthene $(\mathrm{BkF})$, benzo(b)fluoranthene $(\mathrm{BbF})$, benzo(a)pyrene $(\mathrm{BaP})$, dibenzo(ah)anthracene (DBahA) indeno(1,2,3-c,d)pyren (IcdP), and bezo(g,h,i)perylene (BghiP) were determined. The activity of extracellular enzymes $(\beta$-D-cellobiosidase - CB, $\beta$-xylosidase - XYL, $\mathrm{N}$-acetyl- $\beta$-D-glucosaminidase - NAG, phosphatase - PH and arylsulphatase - SP) was determined using fluorogenically labeled substrates (Pritsch et al. 2004; Turner 2010; Sanaullah et al. 2016). The fluorescence was measured on a multidetection plate reader (SpectroMax), with excitation at a wavelength of $355 \mathrm{~nm}$ and emission at $460 \mathrm{~nm}$.

\subsection{Statistical analysis}

The Spearman correlation coefficients for the soil characteristics were calculated. The distribution was checked for normality. $U$ Mann-Whitney test was used to evaluate the differences between the mean values of 
properties. Principal component analysis (PCA) was used to evaluate the relationships between the soil properties and PAH content. A general linear model (GLM) was used to investigate the effect of tree species and soil properties on PAH content. The classification and regression tree $(\mathrm{C} \& \mathrm{RT})$ approach was applied to estimate the influence of tree species and soil properties on PAH content. Differences with $P<0.05$ were considered statistically significant. All the analyses were performed using Statistica 13 software (StatSoft 2012).

\section{Results}

Statistically significant differences in the $\mathrm{pH}$ of the studied soils were observed between deciduous and coniferous species. Independently of the urban forest location, soils of coniferous were characterized by significantly lower $\mathrm{pH}$. The lowest mean $\mathrm{pH}$ in the humus mineral horizon was recorded for Douglas fir ( $\mathrm{pH} \mathrm{H}_{2} \mathrm{O}$ 4.11), and highest for maple $\left(\mathrm{pH} \mathrm{H}_{2} \mathrm{O}\right.$ 6.19) (Table 1). Soils of coniferous species were characterized by a significantly higher hydrolytic and exchange acidity. Highest acidity levels were recorded in organic horizons of coniferous species, in particular pine and spruce (Table 1). Soils of deciduous and coniferous species differed clearly in the content of carbon and nitrogen. The highest organic carbon content was recorded in organic horizons of coniferous species (spruce $23.52 \%$, larch $20.40 \%$, Douglas fir $10.93 \%$ and pine $27.66 \%$ ). Significant difference in the $\mathrm{C} / \mathrm{N}$ ratio between deciduous and coniferous species was found in humus mineral horizons (A). Deciduous species (with the exception for beech) were characterized by a better distribution of organic matter expressed by the $\mathrm{C} / \mathrm{N}$ ratio (Table 1). The studied soils were characterized by high contribution of silt fraction, with lower sand contribution and clay constituted an admixture (Table 2). No significant differences in the content of individual fractions in humus mineral horizons could be found between deciduous and coniferous species (Table 2). Humus mineral horizons of deciduous species were characterized by a significantly higher content of basic cations, in particular of $\mathrm{Ca}$ and $\mathrm{Mg}$.

Soils of the studied deciduous and coniferous species differed in the enzymatic activity, in particular BG, NAG, SP and PH activity. Humus mineral horizons of deciduous species differed statistically significantly by the higher activity of BG, NAG, SP and $\mathrm{PH}$ (Table 3). No significant differences in $\mathrm{CB}$ activity in humus mineral horizons could be found between deciduous and coniferous species. Highest

Table 1 Acidity, carbon and nitrogen content in soil under influence of different tree species

\begin{tabular}{|c|c|c|c|c|c|c|c|c|c|}
\hline Forest & Species & Horizon & $\mathrm{pH} \mathrm{H} \mathrm{H}_{2} \mathrm{O}$ & $\mathrm{pH} \mathrm{KCl}$ & $\begin{array}{l}\mathrm{Hh} \\
\operatorname{cmol}(+) \mathrm{kg}^{-1}\end{array}$ & $\mathrm{Hw}$ & $\begin{array}{l}\mathrm{C} \\
\%\end{array}$ & $\mathrm{~N}$ & $\mathrm{C} / \mathrm{N}$ \\
\hline \multirow[t]{3}{*}{$\mathrm{R}$} & M & A & $6.19 \pm 0.09^{\mathrm{a}}$ & $5.27 \pm 0.13^{\mathrm{a}}$ & $5.98 \pm 0.29^{b}$ & $0.28 \pm 0.04^{\mathrm{b}}$ & $2.28 \pm 0.24^{\mathrm{b}}$ & $0.24 \pm 0.02^{\mathrm{a}}$ & $9.67 \pm 0.23^{\mathrm{b}}$ \\
\hline & $\mathrm{S}$ & $\mathrm{O}$ & $3.91 \pm 0.16$ & $3.23 \pm 0.06$ & $59.79 \pm 3.69$ & $13.11 \pm 1.22$ & $23.52 \pm 1.53$ & $0.99 \pm 0.07$ & $23.86 \pm 0.63$ \\
\hline & & A & $4.27 \pm 0.09^{\mathrm{b}}$ & $3.72 \pm 0.10^{\mathrm{b}}$ & $18.69 \pm 0.91^{\mathrm{a}}$ & $7.61 \pm 0.55^{\mathrm{a}}$ & $3.95 \pm 0.08^{\mathrm{a}}$ & $0.22 \pm 0.01^{\mathrm{a}}$ & $17.60 \pm 0.54^{\mathrm{a}}$ \\
\hline \multirow[t]{3}{*}{ Z } & $\mathrm{R}$ & A & $6.34 \pm 0.34^{\mathrm{a}}$ & $5.78 \pm 0.51^{\mathrm{a}}$ & $3.01 \pm 1.12^{\mathrm{b}}$ & $0.31 \pm 0.08^{\mathrm{b}}$ & $3.97 \pm 0.09^{\mathrm{a}}$ & $0.32 \pm 0.01^{\mathrm{a}}$ & $12.37 \pm 0.09^{b}$ \\
\hline & $\mathrm{L}$ & $\mathrm{O}$ & $4.20 \pm 0.04$ & $3.62 \pm 0.06$ & $44.42 \pm 5.57$ & $7.34 \pm 0.24$ & $20.40 \pm 0.92$ & $1.03 \pm 0.04$ & $19.72 \pm 0.68$ \\
\hline & & A & $4.72 \pm 0.13^{\mathrm{b}}$ & $3.70 \pm 0.40^{\mathrm{b}}$ & $14.58 \pm 1.94^{\mathrm{a}}$ & $3.62 \pm 0.38^{\mathrm{a}}$ & $3.59 \pm 0.32^{\mathrm{a}}$ & $0.24 \pm 0.03^{\mathrm{b}}$ & $14.79 \pm 0.28^{\mathrm{a}}$ \\
\hline \multirow[t]{3}{*}{ W } & B & A & $4.66 \pm 0.14^{\mathrm{a}}$ & $3.75 \pm 0.06^{\mathrm{a}}$ & $11.43 \pm 0.99^{\mathrm{a}}$ & $4.60 \pm 0.07^{\mathrm{b}}$ & $5.22 \pm 0.59^{\mathrm{a}}$ & $0.33 \pm 0.03^{\mathrm{a}}$ & $15.78 \pm 0.34^{\mathrm{a}}$ \\
\hline & $\mathrm{D}$ & $\mathrm{O}$ & $4.04 \pm 0.08$ & $3.35 \pm 0.04$ & $22.45 \pm 2.16$ & $7.79 \pm 0.39$ & $10.93 \pm 0.75$ & $0.51 \pm 0.04$ & $21.34 \pm 0.40$ \\
\hline & & A & $4.11 \pm 0.01^{\mathrm{b}}$ & $3.41 \pm 0.02^{\mathrm{b}}$ & $11.80 \pm 0.74^{\mathrm{a}}$ & $6.16 \pm 0.25^{\mathrm{a}}$ & $3.49 \pm 0.19^{\mathrm{b}}$ & $0.25 \pm 0.01^{\mathrm{b}}$ & $13.84 \pm 0.64^{\mathrm{b}}$ \\
\hline \multirow[t]{3}{*}{$\mathrm{T}$} & $\mathrm{O}$ & A & $5.42 \pm 0.40^{\mathrm{a}}$ & $4.71 \pm 0.59^{\mathrm{a}}$ & $5.17 \pm 1.95^{\mathrm{b}}$ & $0.96 \pm 0.66^{\mathrm{b}}$ & $3.72 \pm 0.16^{\mathrm{a}}$ & $0.24 \pm 0.01^{\mathrm{a}}$ & $15.21 \pm 0.41^{\mathrm{b}}$ \\
\hline & $\mathrm{P}$ & $\mathrm{O}$ & $3.90 \pm 0.13$ & $3.36 \pm 0.16$ & $46.15 \pm 1.29$ & $8.42 \pm 0.48$ & $27.66 \pm 0.48$ & $1.26 \pm 0.09$ & $22.04 \pm 1.35$ \\
\hline & & A & $4.38 \pm 0.06^{\mathrm{b}}$ & $3.46 \pm 0.06^{\mathrm{b}}$ & $18.52 \pm 1.25^{\mathrm{a}}$ & $5.07 \pm 0.61^{\mathrm{a}}$ & $4.03 \pm 0.16^{\mathrm{a}}$ & $0.25 \pm 0.02^{\mathrm{a}}$ & $16.39 \pm 0.60^{\mathrm{a}}$ \\
\hline
\end{tabular}

Urban forest: $R$, Reduta forest; $Z$, Zesławice forest; $W$, Wolski forest; $T$, Tyniec Forest. Species: $M$, maple; $S$, spruce, $R$, Robinia; $L$, larch, $B$, beech; $D$, Douglas fir; $O$, oak; $P$, pine. Horizon: $A$, mineral humus horizon; $O$, organic horizon; $H h$, hydrolytic acidity; $H w$, exchangeable acidity; $C$, organic carbon; $N$, total nitrogen. Small letters in the upper index of the mean values mean significant differences between species in humus mineral horizon $(\mathrm{A})$ 


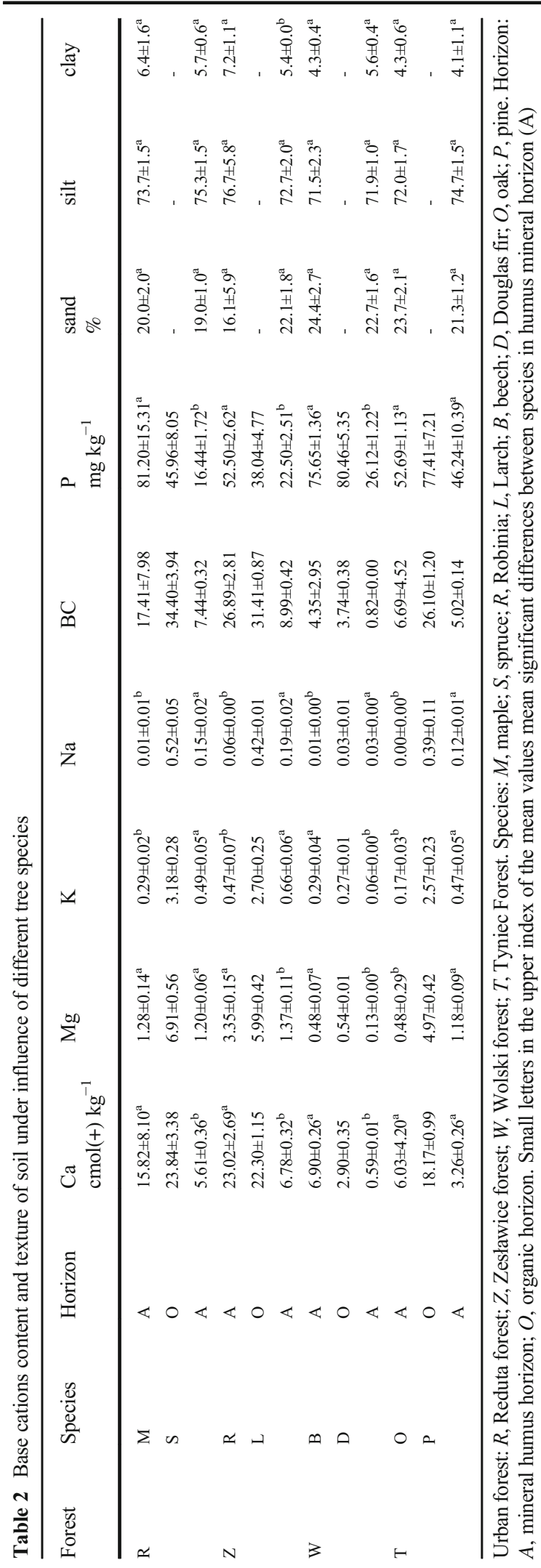

PAH accumulation characterized organic horizons of coniferous tree stands (Fig. 2). The highest total PAH content was recorded in organic horizons of pine tree stands (mean content was $1.91 \mu \mathrm{g} \mathrm{g}^{-1}$ ). In all investigated urban forest locations, the humus mineral horizons (A) of coniferous species exhibited statistically significantly higher PAH accumulation in comparison to deciduous species. Mean total PAH level in humus mineral horizons of coniferous species ranged from $0.196 \mu \mathrm{g} \mathrm{g}^{-1}$ to $0.385 \mu \mathrm{g} \mathrm{g}^{-1}$, and for deciduous species from $0.061 \mu \mathrm{g} \mathrm{g}^{-1}$ to $0.146 \mu \mathrm{g} \mathrm{g}^{-1}$ (Fig. 2). 4- and 5-ring hydrocarbons were predominant in the investigated soils independently of the analysed horizon and species (Table 4). In the soils of the investigated tree stands, no 2-ring PAHs could be found and the contribution of 3-ring hydrocarbons was minor (Table 4). In the humus mineral horizon, the total PAH level was statistically significantly and negatively correlated with $\mathrm{pH}$ and content of base cations, and positively correlated with acidity and $\mathrm{C} / \mathrm{N}$ ratio (Table 5 ). The activity of BG, NAG, SP, and PH in the A horizon negatively correlated with total PAH level $(r=-0.887$, $r=-0.823, r=-0.804$ and $r=-0.777$, respectively). In addition, the enzymatic activity correlated positively with $\mathrm{pH}$, base cation content and $\mathrm{P}$ content and negatively with soil acidity (Table 5). GLM analysis confirmed the significance of biochemical activity expressed by $\beta$-glucosidase activity in the formation of PAH accumulation (Table 6). In addition, significance of species and organic carbon content in the formation of PAH amount was revealed. PCA analysis confirmed a clear relationship between acidification of the investigated soils, amount of organic carbon and the degree of soil organic matter decomposition expressed by the $\mathrm{C} / \mathrm{N}$ ratio (Fig. 3). The two primary factors had a significant impact on the variance of properties $(77.7 \%)$. PCA indicated strong relationship of organic horizons of coniferous species with acidification, accumulation of poorly decomposed organic matter and high $\mathrm{PAH}$ accumulation. PCA produced clear groups of humus mineral horizons of deciduous and coniferous species in terms of acidification, quantity and quality of soil organic matter, biochemical activity and above all PAH content (Fig. 3). Classification and regression tree charts were used to identify the characteristics that determine PAH accumulation in urban forest soils (Fig. 4). They are type of soil horizon, species, 


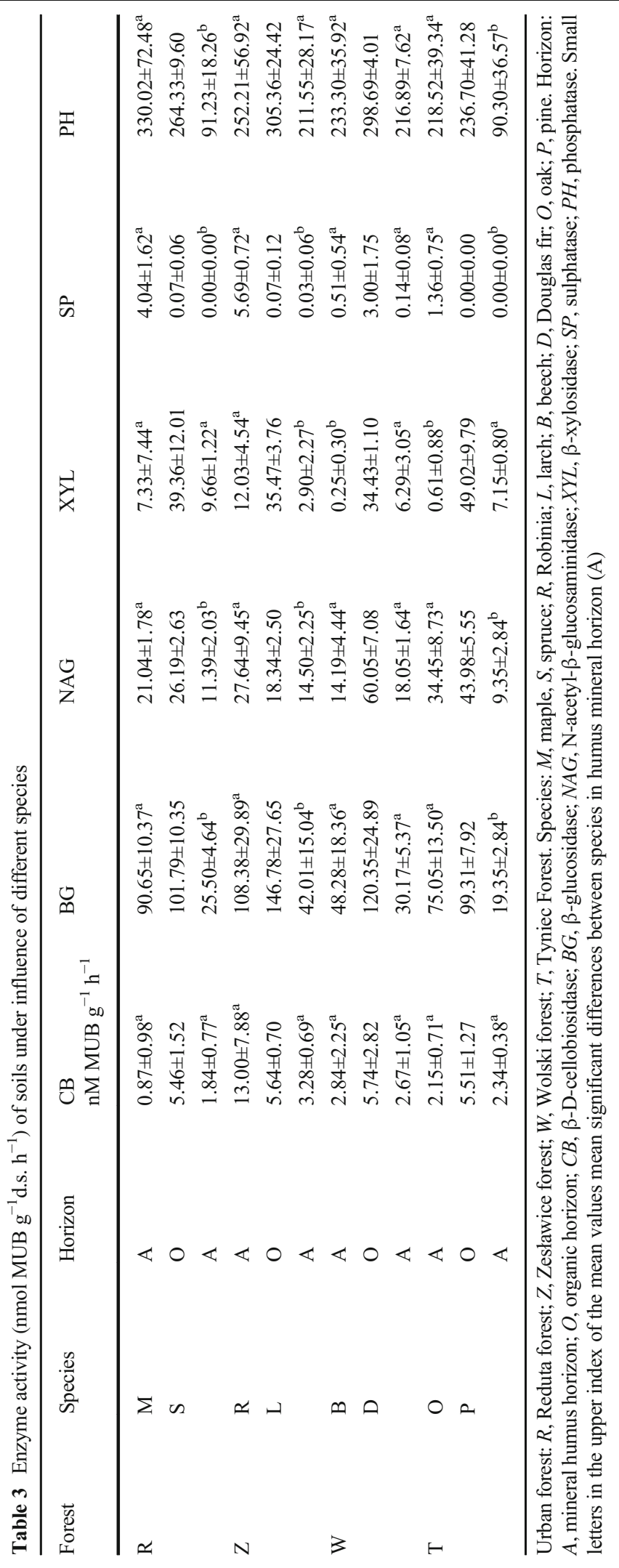


Fig. 2 Sum of PAH content in soil under influence of different species (M, maple; S, spruce; R, Robinia; L, larch; B, beech; D, Douglas fir; $\mathrm{O}$, oak; $\mathrm{P}$, pine)

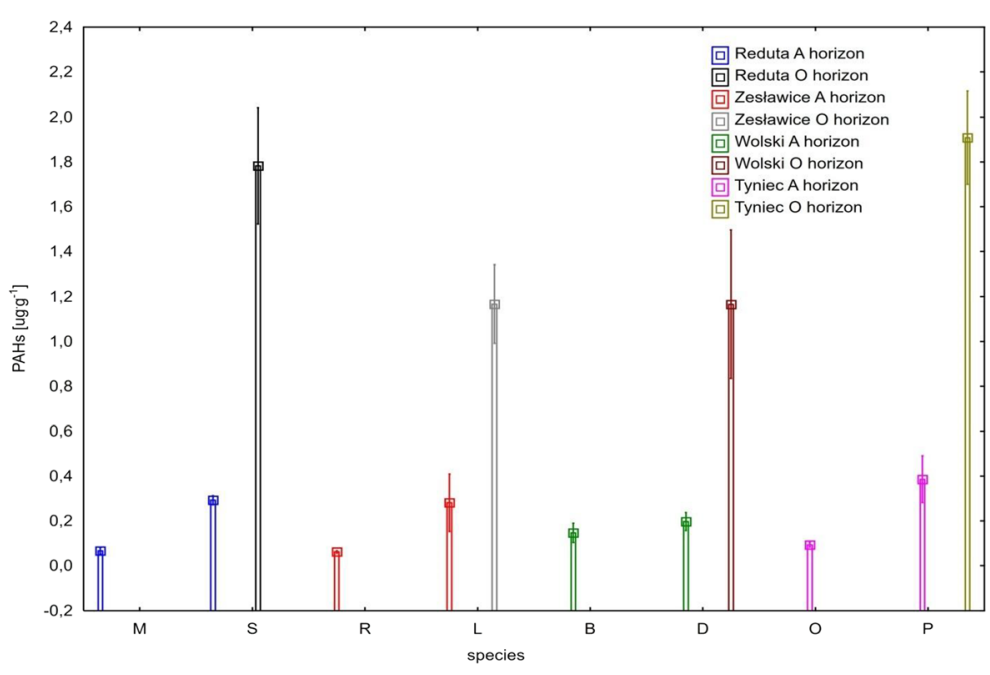

$\beta$-glucosidase activity and $\mathrm{C} / \mathrm{N}$ ratio. The highest $\mathrm{PAH}$ accumulation was fund in organic horizon at a BG activity $<114.04$ nmol MUB g ${ }^{-1}$ d.s. $h^{-1}$ and $\mathrm{C} / \mathrm{N}>21.7$ (Fig. 4).

\section{Discussion}

The conducted research has confirmed the validity of the advanced research hypotheses. Species composition is important in PAH accumulation in urban forests of Krakow. By means of the provided organic matter, tree species affect the chemical properties of soils, and as a consequence the biochemical activity and biodegradation of PAHs. Deciduous species provide soil with easily decomposable organic matter, and the components released during its decomposition raise soil $\mathrm{pH}$. We recorded lower $\mathrm{PAH}$ accumulation under deciduous tree stands in urban forests of Krakow. Soils of such stands were characterized by higher $\mathrm{pH}$ and higher biochemical activity expressed by the activity of enzymes involved in the cycle of $\mathrm{C}, \mathrm{N}, \mathrm{P}$ and $\mathrm{S}$. According to Maliszewska-Kordybach (2005), some soil properties (acidity, content of fine fractions and organic matter content) affect the course of PAH decomposition. Soil characteristics greatly influence the efficiency of microbial PAH degradation (Zhang et al. 2006; Lors et al. 2012). Better quality of soil organic matter was observed for deciduous stands, expressed as the $\mathrm{C} / \mathrm{N}$ ratio. Lowered nitrogen availability may restrict the activity of soil microorganisms, and thus the processes of organic matter decomposition (Treseder 2008; Averill and Waring 2017). According to Zhou and Hua (2004), appropriate level of nutrients, particularly of nitrogen, is necessary for improved PAH bioremediation. Earlier study indicates marked differences in the release of nutrients, particularly of $\mathrm{C}, \mathrm{N}$ and $\mathrm{P}$ during the decomposition of plant litter of deciduous and coniferous species (Błońska et al. 2021). More carbon and nitrogen are released to soil from deciduous litter than from coniferous litter, which results in increased activity and diversity of the microbial community. Apart from the fall of plant litter, tree stands affect soil properties via their root systems, which apart from organic matter provide nutrients via root secretions. Root secretions provide soil with sugars, amino acids, organic acids, hormones and vitamins as well as high-molecular compounds such as enzymes, which translates into higher metabolic activity of the microflora, which is abundant in the rhizosphere (Lu et al. 2012). Earlier research confirmed the increased biodegradation rate of organic contaminants in the rhizosphere zone as compared with non-rhizosphere zone (Zhuang et al. 2007). Wang et al. (2019) found that the influence of deciduous rhizosphere on the microorganism biomass, enzyme activity and $\mathrm{N}$ mineralization rate was 2 -fold higher than for coniferous species. The tree stand species composition has a very pronounced effect on soil $\mathrm{pH}$, which is of key significance for PAH biodegradation. According to Pawar (2015), biodegradation processes can be enhanced by considering the 
Table 4 PAH content $\left(\mu \mathrm{g} \mathrm{g}^{-1}\right)$ in soil under influence different species taking into account the number of rings

\begin{tabular}{|c|c|c|c|c|c|}
\hline & & & \multirow{2}{*}{$\begin{array}{l}\text { Broadleaved species } \\
\text { A - horizon }\end{array}$} & \multicolumn{2}{|l|}{ Coniferous species } \\
\hline & & & & $\mathrm{O}$ - horizon & A - horizon \\
\hline \multirow[t]{10}{*}{ LMW } & \multirow[t]{5}{*}{ 3rings } & Flu & $0.00000 \pm 0.00000^{\mathrm{a}}$ & $0.00066 \pm 0.00065$ & $0.00000 \pm 0.00000^{\mathrm{a}}$ \\
\hline & & Ant & $0.00000 \pm 0.00000^{\mathrm{a}}$ & $0.00012 \pm 0.00022$ & $0.00000 \pm 0.00000^{\mathrm{a}}$ \\
\hline & & Ace & $0.00044 \pm 0.00040^{\mathrm{b}}$ & $0.01363 \pm 0.00577$ & $0.00218 \pm 0.00141^{\mathrm{a}}$ \\
\hline & & Phe & $0.02021 \pm 0.00974^{\mathrm{b}}$ & $0.09447 \pm 0.03375$ & $0.03261 \pm 0.00808^{\mathrm{a}}$ \\
\hline & & $\sum$ & $0.02065 \pm 0.00990^{\mathrm{b}}$ & $0.10888 \pm 0.03920$ & $0.03479 \pm 0.00925^{\mathrm{a}}$ \\
\hline & \multirow[t]{5}{*}{ 4rings } & Flt & $0.01337 \pm 0.00817^{\mathrm{b}}$ & $0.29030 \pm 0.10936$ & $0.04715 \pm 0.02055^{\mathrm{a}}$ \\
\hline & & Pyr & $0.01209 \pm 0.00742^{\mathrm{b}}$ & $0.28454 \pm 0.07566$ & $0.06026 \pm 0.06110^{\mathrm{a}}$ \\
\hline & & $\mathrm{BaA}$ & $0.00509 \pm 0.00301^{\mathrm{b}}$ & $0.14098 \pm 0.04033$ & $0.03061 \pm 0.03692^{\mathrm{a}}$ \\
\hline & & $\mathrm{Chr}$ & $0.00965 \pm 0.00626^{\mathrm{b}}$ & $0.25943 \pm 0.07022$ & $0.03970 \pm 0.01897^{\mathrm{a}}$ \\
\hline & & $\sum$ & $0.04020 \pm 0.02417^{\mathrm{b}}$ & $0.97526 \pm 0.28004$ & $0.17772 \pm 0.07720^{\mathrm{a}}$ \\
\hline \multirow[t]{9}{*}{ HMW } & \multirow[t]{5}{*}{ 5rings } & $\mathrm{BbF}$ & $0.01436 \pm 0.00376^{\mathrm{b}}$ & $0.13371 \pm 0.03306$ & $0.02935 \pm 0.00882^{\mathrm{a}}$ \\
\hline & & $\mathrm{BaP}$ & $0.00641 \pm 0.00324^{\mathrm{b}}$ & $0.12605 \pm 0.02902$ & $0.02148 \pm 0.01099^{\mathrm{a}}$ \\
\hline & & $\mathrm{BkF}$ & $0.00256 \pm 0.00171^{\mathrm{a}}$ & $0.02834 \pm 0.01590$ & $0.00348 \pm 0.00140^{\mathrm{a}}$ \\
\hline & & DBahA & $0.00013 \pm 0.00005^{\mathrm{b}}$ & $0.00211 \pm 0.00092$ & $0.00071 \pm 0.00102^{\mathrm{a}}$ \\
\hline & & $\sum$ & $0.02346 \pm 0.00821^{\mathrm{b}}$ & $0.29021 \pm 0.07037$ & $0.05502 \pm 0.02042^{\mathrm{a}}$ \\
\hline & \multirow[t]{4}{*}{ 6rings } & BghiP & $0.00319 \pm 0.00133^{\mathrm{b}}$ & $0.04070 \pm 0.00945$ & $0.00763 \pm 0.00310^{\mathrm{a}}$ \\
\hline & & IcdP & $0.00443 \pm 0.00212^{\mathrm{b}}$ & $0.09033 \pm 0.02536$ & $0.01390 \pm 0.00673^{\mathrm{a}}$ \\
\hline & & $\sum$ & $0.00762 \pm 0.00332^{\mathrm{b}}$ & $0.13103 \pm 0.03476$ & $0.02153 \pm 0.00973^{\mathrm{a}}$ \\
\hline & & $\sum$ PAHs & $0.09192 \pm 0.04052^{\mathrm{b}}$ & $1.50537 \pm 0.41661$ & $0.28905 \pm 0.10111^{\mathrm{a}}$ \\
\hline
\end{tabular}

PAH: Flu, fluoranthene; Ant, anthracene; Ace, acenapthene; Phe, phenanthrene; Flt, fluoranthene; Pyr, pyrene; BaA, Benzo(a)anthracene; $C h r$, chrysene; $B b F$, benzo(b)fluoranthene; $B a P$, benzo(a)pyrene; $B k F$, benzo(k)fluoranthene; $D B a h A$, dibenz(a,h)anthracene; $B g h i P$, benzo(g,h,i)perylene; $I c d P$, indeno(1,2,3-cd)perylene; $L M W$, low molecular weight PAHs; $H M W$, high molecular weight. Small letters in the upper index of the mean values mean significant differences between broadleaved and coniferous species in humus mineral horizon (A)

enzymes present in soil and their active role varying $\mathrm{pH}$ values. The capacity of microorganisms to degrade PAHs in soil environment depends on the physical and chemical properties of soils, in particular on its $\mathrm{pH}$. Higher soil $\mathrm{pH}$ results in higher activity of microorganisms, whereas the diversity and activity of microorganisms are limited in acidic environment (Uzarowicz et al. 2020). According to the aforementioned authors, the low enzymatic activity and low bacterial counts were associated with highly acidic soils $\left(\mathrm{pH} \mathrm{H}_{2} \mathrm{O}\right.$ 3.0-3.9). It can be assumed that higher PAH accumulation in soils with coniferous stands is associated with their acidifying effect. The acidifying effect of tree species on sandy

Table 5 Correlations between enzyme activity, PAH content and soil properties in mineral humus horizon (A)

\begin{tabular}{llllllllll}
\hline & $\mathrm{pH} \mathrm{H} 2 \mathrm{O}$ & $\mathrm{pH} \mathrm{KCl}$ & $\mathrm{Hh}$ & $\mathrm{BC}$ & $\mathrm{C}$ & $\mathrm{N}$ & $\mathrm{C} / \mathrm{N}$ & $\mathrm{P}$ & $\mathrm{PAHs}$ \\
\hline $\mathrm{PAHs}$ & $-0.830^{*}$ & $-0.755^{*}$ & $0.891^{*}$ & $-0.601^{*}$ & 0.382 & -0.126 & $0.697^{*}$ & $-0.549^{*}$ & 1.000 \\
$\mathrm{CB}$ & 0.168 & 0.062 & -0.231 & 0.129 & 0.211 & 0.350 & -0.104 & -0.079 & 0.050 \\
$\mathrm{BG}$ & $0.854^{*}$ & $0.785^{*}$ & $-0.914^{*}$ & $0.622^{*}$ & -0.240 & 0.244 & $-0.713^{*}$ & $0.503^{*}$ & $-0.887^{*}$ \\
$\mathrm{NAG}$ & $0.632^{*}$ & $0.611^{*}$ & $-0.878^{*}$ & 0.283 & $-0.417^{*}$ & 0.094 & $-0.702^{*}$ & 0.357 & $-0.823^{*}$ \\
$\mathrm{XYL}$ & -0.051 & 0.085 & 0.091 & 0.154 & 0.060 & -0.004 & -0.071 & -0.243 & 0.273 \\
$\mathrm{SP}$ & $0.760^{*}$ & $0.764^{*}$ & $-0.915^{*}$ & $0.508^{*}$ & -0.250 & 0.263 & $-0.776^{*}$ & $0.569^{*}$ & $-0.804^{*}$ \\
$\mathrm{PH}$ & $0.643^{*}$ & $0.475^{*}$ & $-0.785^{*}$ & $0.431^{*}$ & $-0.405^{*}$ & 0.133 & $-0.700^{*}$ & $0.516^{*}$ & $-0.777^{*}$ \\
\hline
\end{tabular}

$* p<0.05$ 
Table 6 Summary of GLM analysis of the effect of the soil properties and tree species on the PAH content

\begin{tabular}{lll}
\hline & $\mathrm{F}$ & $p$ value \\
\hline Species & 1.770 & 0.1907 \\
$\mathrm{pH}$ & 0.046 & 0.8343 \\
$\mathrm{C}$ & 0.094 & 0.7652 \\
$\mathrm{BG}$ & $\mathbf{1 7 . 4 3 1}$ & $\mathbf{0 . 0 0 1 5}$ \\
Species $\times \mathrm{pH}$ & 1.850 & 0.1737 \\
Species $\times \mathrm{C}$ & $\mathbf{6 . 3 5 6}$ & $\mathbf{0 . 0 0 3 6}$ \\
\hline
\end{tabular}

bold values $-p<0.05$

soil was in the order of spruce $=$ pine $>$ oak, while that on loess was pine $>$ beech $>$ hornbeam (Błońska et al. 2016b). Our study shows stronger degradation of PAHs in soils with deciduous tree stands, which are characterized by higher $\mathrm{pH}$ and higher biochemical activity expressed by enzymatic activity. Statistically significant difference in the activity of enzymes involved in $\mathrm{C}, \mathrm{N}, \mathrm{P}$ and $\mathrm{S}$ transformations in deciduous stand soils was observed in comparison with coniferous stands, which results in the differences of PAH accumulation. Among the studied deciduous species, highest enzymatic activity characterized soils were Norway maple and locust. At the same time, soils under these species were characterized by the lowest PAH accumulation. Among the coniferous species, highest PAH accumulation was observed under pine and spruce, where low enzymatic activity was observed at the same time. In our study, we have been able to record a strong relationship of the enzymatic activity with $\mathrm{pH}$ and with organic carbon content. The $\mathrm{pH}$ value has a significant effect on the activity of microorganisms in the soil, and many enzymes are very sensitive to the $\mathrm{pH}$ of soil. The soil $\mathrm{pH}$ influences the activity of soil enzymes by controlling ionization caused by conformational changes of enzymes, availability of substrates and enzymatic cofactors (Błońska et al. 2021). Soil organic matter is the main source of enzyme substrate, and the content of organic matter greatly affects the activity of soil enzyme (Zhang et al. 2020). It has been recognized that PAHs are degraded by the synthesis of lignin modifying enzymes like lignin peroxidases, manganese peroxidases laccases and other oxidases (Cao et al. 2020). Catabolic activity of microorganisms in PAH degradation depends largely on the environmental conditions ( $\mathrm{pH}$, temperature and nutrients), counts and type of microorganisms, character or properties of the degraded PAHs (Singh and Ward

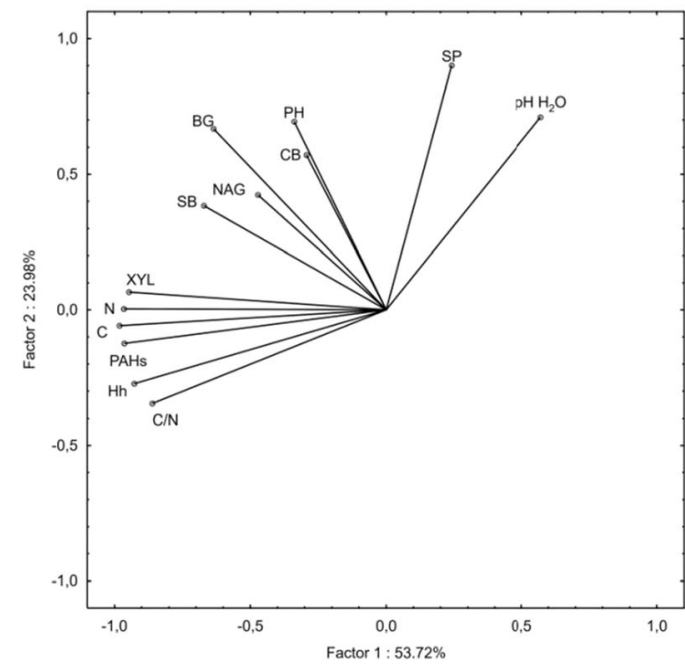

Fig. 3 The projection of variables on a plane of the first and second PCA factor ( $\mathrm{DH}$, dehydrogenase activity; $\mathrm{CB}, \beta-\mathrm{D}-$ cellobiosidase; XYL, $\beta$ xylosidase; NAG, N-acetyl- $\beta$-Dglucosaminidase; $\mathrm{BG}, \beta$-glucosidase; $\mathrm{PH}$, phosphatase; SP, arylosulphatase; $\mathrm{C}$, organic carbon content; $\mathrm{N}$, total nitrogen content; Hh, hydrolytic acidity; black circle, organic horizon of

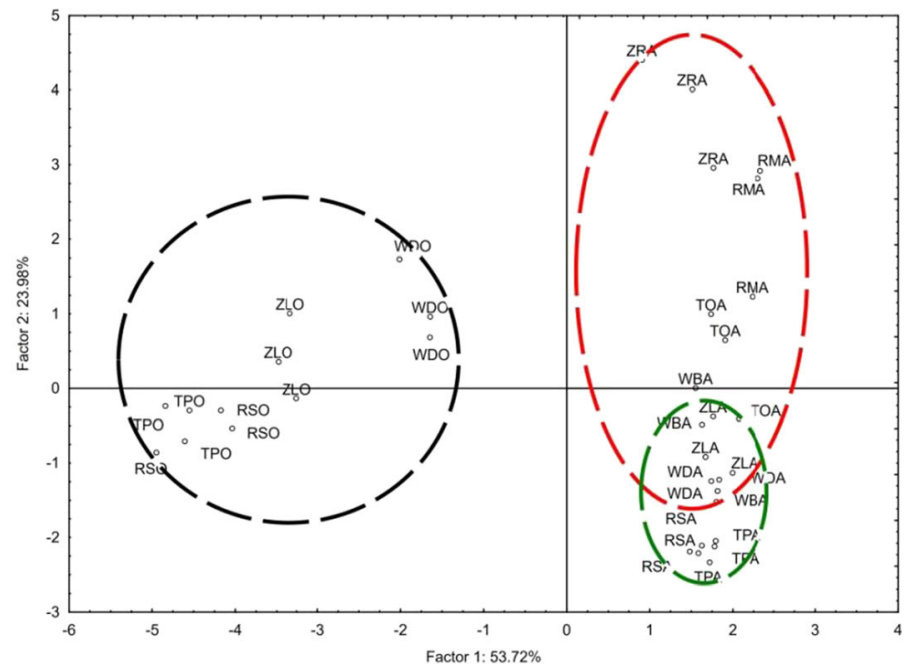

coniferous species; red circle, humus mineral horizon of broadleaved species; green circle, humus mineral horizon of coniferous species; R, Reduta forest; Z, Zesławice forest; W, Wolski forest; T, Tyniec Forest; species: M, maple; S, spruce; R, Robinia; L, larch; B, beech; D, Douglas fir; O, oak; P, pine) 


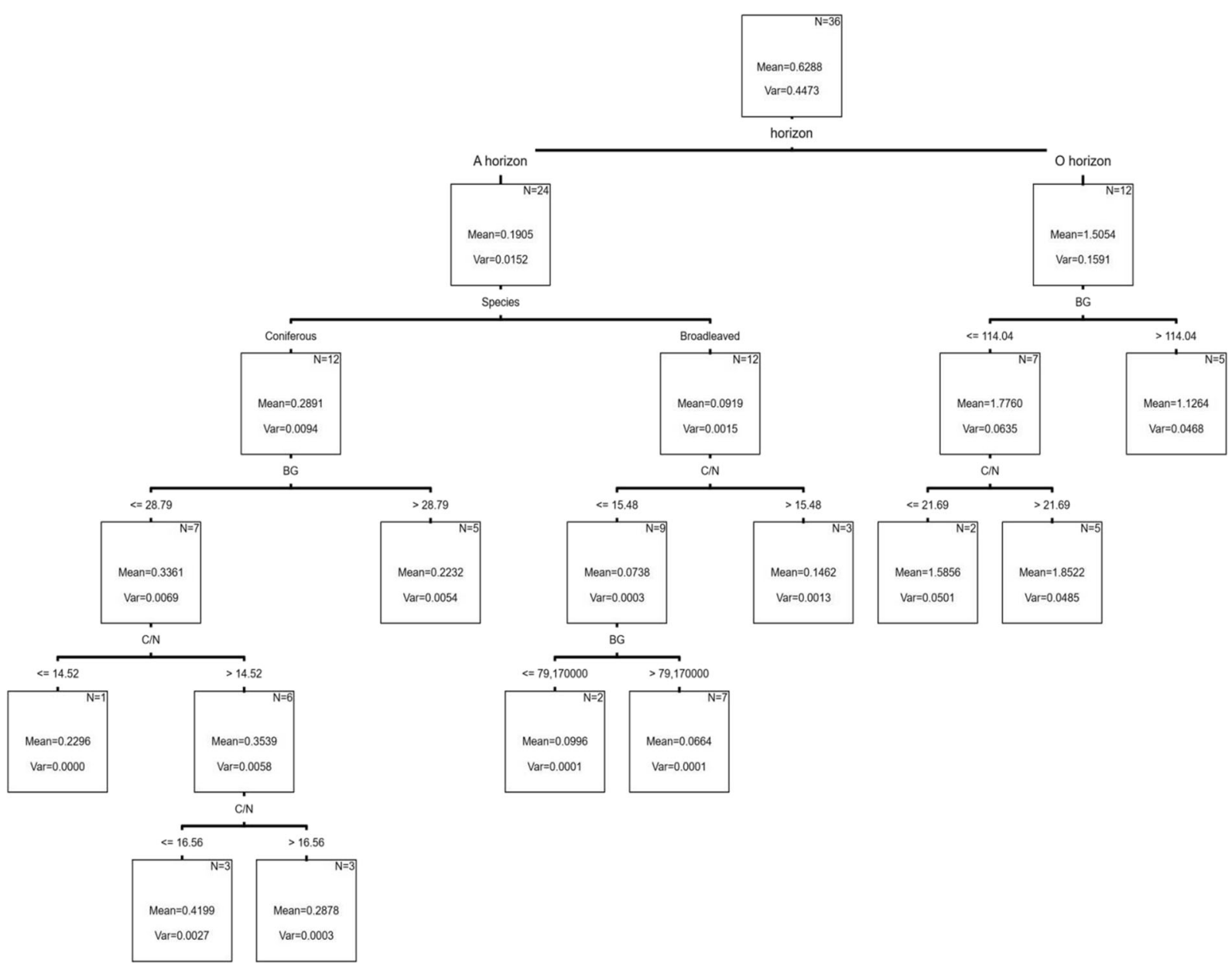

Fig. 4 The regression tree $(C \& R T)$ for PAH content in soil

2004). PAH biodegradation is activated by different catalytic enzymes secreted by microorganisms. According to Suszek-Łopatka et al. (2019), the increase of soil moisture enhanced PAH toxicity differently depending on the soil. Our study included soils with similar moisture; therefore, this factor did not influence the amount of PAH. Different microbe species such as Pseudomonas, Sphingomonas, Micrococcus, Xanthomonas, Corynebacterium, Enterobacter, Paenibacillus, Bacillus, Aeromonas, Microbulbifer, Mycobacteria, Acinetobacter and Aspergillus are characterized by PAH biodegradation capacity (Sakshi and Haritash 2020). At the same time with PAHs, significant amounts of heavy metals accumulate in the surface horizon of urban soils (RodriguezSeijo et al. 2015). According to Ciarkowska et al. (2019), the Krakow soils were characterized by the high levels of PAHs and heavy metals. It can be assumed that PAH and heavy metals inhibited enzymatic activity in the study soils of Krakow.

\section{Conclusions}

The conducted study has confirmed the importance of tree stand species composition in the formation of soil properties, and consequently PAH biodegradation in the urban forests of Krakow. Via the appropriate selection of species we can influence on the quantity and quality of soil organic matter and soil $\mathrm{pH}$, which results in the diversification and activity of soil microorganisms participating in the distribution of organic pollutants. Our study shows that deciduous, and in particular Norway maple and locust have more favourable influence on soil 
properties, which translates into lower PAH accumulation in the urban forests of Krakow. Introduction of coniferous species, in particular of pine and spruce, should be avoided in urban forests, as they have acidifying effect on soil, thus restricting the processes of decomposition, in which soil microorganisms are involved. The value of $\mathrm{pH}$ has turned out to be an important parameter in PAH biodegradation in urban forest soils of Krakow, because it comprises the key factor for the availability of nutrients, and thus for the development of microorganisms involved in PAH decomposition.

Author contribution Conceptualization, J.L., S.Ł., E.B.; methodology, J.L., S.Ł., P.K., M.K., E.B.; material collection, J.L., S.Ł., P.K., M.K., E.B.; laboratory analyses, J.L., S.Ł., P.K., M.K., E.B.; writing, J.L., S.E., P.K., M.K., E.B.

Funding This work was supported by the Ministry of Science and Higher Education of the Republic of Poland (SUB/040012/ D019; A425, A428).Code AvailabilityNot applicable.

\section{Declarations}

Conflict of Interest The authors declare no competing interests.

Ethics Approval Not applicable.

\section{Consent to Participate Not applicable.}

Consent for Publication Not applicable.

Open Access This article is licensed under a Creative Commons Attribution 4.0 International License, which permits use, sharing, adaptation, distribution and reproduction in any medium or format, as long as you give appropriate credit to the original author(s) and the source, provide a link to the Creative Commons licence, and indicate if changes were made. The images or other third party material in this article are included in the article's Creative Commons licence, unless indicated otherwise in a credit line to the material. If material is not included in the article's Creative Commons licence and your intended use is not permitted by statutory regulation or exceeds the permitted use, you will need to obtain permission directly from the copyright holder. To view a copy of this licence, visit http://creativecommons.org/licenses/by/4.0/.

\section{References}

Averill, C., \& Waring, B. (2017). Nitrogen limitation of decomposition and decay: how can it occur? Global Change Biology, 24, 1417-1427.
Błaszczyk, E., Rogula-Kozłowska, W., Klejnowski, K., Fulara, I., \& Mielżyńska-Švach, D. (2017). Polycyclic aromatic hydrocarbons bound to outdoor and indoor airborne particles (PM2.5) and their mutagenicity and carcinogenicity in Silesian kindergartens, Poland. Air Quality Atmosphere Health, 10, 389-400.

Błońska, E., Lasota, J., Szuszkiewicz, M., Łukasik, A., \& Klamerus-Iwan, A. (2016a). Assessment of forest soil contamination in Krakow surroundings in relation to the type of stand. Environmental Earth Sciences, 75(16), 1-15.

Błońska, E., Lasota, J., \& Gruba, P. (2016b). Effect of temperate forest tree species on soil dehydrogenase and urease activities in relation to other properties of soil derived from loess and glaciofluvial sand. Ecological Research, 31(5), 655-664.

Błońska, E., Lasota, J., \& Gruba, P. (2017). Enzymatic activity and stabilization of organic matter in soil with different detritus inputs. Journal of Soil Science and Plant Nutrition, 63, 242-247.

Błońska, E., Piaszczyk, W., Staszel, K., \& Lasota, J. (2021). Enzymatic activity of soils and soil organic matter stabilization as an effect of components released from the decomposition of litter. Applied Soil Ecology, 157, 103723.

Cao, H., Wang, C., Liu, H., Jia, W., \& Sun, H. (2020). Enzyme activities during Benzo(a)pyrene degradation by the funguj Lasidiplodia theobromae isolated from a polluted soil. Scientific Report, 10, 865.

Ciarkowska, K., Gambuś, F., Antonkiewicz, J., \& Koliopoulos, T. (2019). Polycyclic aromatic hydrocarbon and heavy metal content in the urban soils in southern Poland. Chemosphere, 229, 214-226.

Deng, Q., Cheng, X., Hui, D., Zhang, Q., Li, M., \& Zhang, Q. (2016). Soil microbial community and its interaction with soil carbon and nitrogen dynamics following afforestation in Central China. Science of the Total Environmental, 541, 230-237.

Gan, S., Lau, E., \& Ng, H. (2009). Remediation of soils contaminated with polycyclic aromatic hydrocarbons (PAhs). Journal of Hazardous Materials, 172, 532-549.

Graça, M. A. S., \& Poquet, J. M. (2014). Do climate and soil influence phenotypic variability in leaf litter, microbial decomposition and shredder consumption? Oecologia, 174, $1021-1032$.

Lasota, J., \& Błońska, E. (2018). Polycyclic aromatic hydrocarbons content in contamined forest soils with different humus type. Water Air and Soil Pollution, 229, 204.

Loeppmann, S., Blagodatskaya, E., Pausch, J., \& Kuzyakov, Y. (2016). Enzyme properties down the soil profile - A matter of substrate quality in rhizosphere and detritusphere. Soil Biology and Biochemistry, 103, 274-283.

Lors, C., Damidot, D., Ponge, J. F., \& Périé, F. (2012). Comparison of a bioremediation process of PAHs in a PAH-contaminated soil at field and laboratory scales. Environmental Pollution, 165, 11-17.

Lu, X. Y., Li, B., Zhang, T., \& Fang, H. (2012). Enhanced anoxic bioremediation of PAHs-contaminated sediment. Bioresource Technology, 104, 51-88.

Luo, L., Lin, S., Huang, H., \& Zhang, S. (2012). Relationships between aging of PAHs and soil properties. Environmental Pollution, 170, 177-182.

Maliszewska-Kordybach, B. (2005). Dissipation of polycyclic aromatic hydrocarbons in freshly con-taminated soils - the 
effect of soil physicochemical properties and aging. Water Air Soil Pollution, 168, 113-128.

Marston, C. P., Pereira, C., Ferguson, J., Fischer, K., Hedstrom, O., \& Dashwood, W. M. (2001). Effect of a complex environmental mixture from coal for containing polycyclic aromatic hydrocarbons (PAH) on the tumor initiation, PAHDNA minding and metabolic activation of carcinogenic PAH in mouse epidermis. Carcinogenesis, 22, 1077-1086.

Mrozik, A., Piotrowska, S. Z., \& Labuzek, S. (2003). Bacterial degradation and bioremediation of polycyclic aromatic hydrocarbons. Polish Journal of Environmental Studies, 12(1), $15-21$.

Oleszczuk, P. (2007). Organic pollutants in sewage sludgeamended soil part II. Fate of contaminants soils. Ecological Chemistry and Engineering, 14, 185-198.

Ostrowska, A., Gawliński, S., \& Szczubiałka, Z. (1991). Methods of analysis and assessment of soil and plant properties. Warszawa: Environmental Protection Institute (in Polish).

Pawar, R. M. (2015). The effect of soil pH on bioremediation of polycyclic aromatic hydrocarbons (PAHs). Journal of Bioremediation and Biodegradation, 6, 3.

Pritsch, K., Raidl, S., Marksteiner, E., Blaschke, H., Agerer, R., Schloter, M., \& Hartmann, A. (2004). A rapid and highly sensitive method for measuring enzyme activities in single mycorrhizal tips using 4-methylumbelliferone-labelled fluorogenic substrates in a microplate system. Journal of Microbiological Methods, 58(2), 233-241.

Rodriguez-Seijo, A., Andrade, M. L., \& Vega, F. A. (2015). Origin and spatial distribution ofmetals in urban soils. Journal of Soils and Sediments, 1-13. https://doi. org/10.1007/s11368-015-1304-2.

Sakshi, \& Haritash, A. K. (2020). A comprehensive review of metabolic and genomic aspects of PAH-degradation. Archives of Microbiology, 202, 2033-2058.

Sanaullah, M., Razavi, B. S., Blagodatskaya, E., \& Kuzyakov, Y. (2016). Spatial distribution and catalytic mechanisms of $\beta$ glucosidase activity at the root-soil interface. Biology and Fertility of Soils, 52, 505-514.

Singh, A., \& Ward, O. P. (2004). Biodegradation and bioremediation: series: soil biology (Vol. 2). New York: SpringerVerlag.

Skiba, S., \& Drewnik, M. (2013). Directions of agricultural development. In B. Degórska \& M. Baścik (Eds.), The natural environment of Krakow. Reosurces - protection - shaping (pp. 225-229). Kraków: Publishing House of the Institute of Geography and Spatial Management UJ.

Srogi, K. (2007). Monitoring of environmental exposure to polycyclic aromatic hydrocarbons: a review. Environmental Chemistry Letters, 5, 169-195.

StatSoft Inc., 2012. STATISTICA (version 13.0). Computer software.

Suszek-Łopatka, B., Maliszewska-Kordybach, B., KlimkowiczPawlas, A., \& Smreczak, B. (2019). The drought and high wet soil condition impact on PAH (phenanthrene) toxicity towards nitrifying bacteria. Journal of Hazardous Materials, $368,274-280$.

Treseder, K. K. (2008). Nitrogen additions and microbial biomass: a meta-analysis of ecosystem studies. Ecology Letters, 11, $1111-1120$
Turner, B. L. (2010). Variation in pH optima of hydrolytic enzyme activities in tropical rain forest soils. Applied and Environmental Microbiology, 76(19), 6485-6493.

Uzarowicz, Ł., Wolińska, A., Błońska, E., SzafranekNakonieczna, A., Kuźniar, A., Słodczyk, Z., \& Kwasowski, W. (2020). Technogenic soils (Technosols) developed from mine spoils containing Fe sulphides: microbiological activity as an indicator of soil development following land reclamation. Applied Soil Ecology, 156, 103699.

Van Der Heijden, M. G., Bardgett, R. D., \& Van Straalen, N. M. (2008). The unseen majority: soil microbes as drivers of plant diversity and productivity in terrestrial ecosystems. Ecology Letters, 11, 296-310.

Wang, Z., Chen, S., Xu, Y., \& Tang, J. (2012). Aging effects on sorption-desorption behaviours of PAHs in different natural organic matters. Journal of Colloid and Interface Science, 382(1), 117-122.

Wang, Q., Xiao, J., Ding, J., Zou, T., Zhang, Z., Liu, Q., \& Yin, H. (2019). Differences in root exudates inputs and rhizosphere effects on soil $\mathrm{N}$ transformation between deciduous and evergreen trees. Plant and Soil. https://doi.org/10.1007 /s11104-019-04156-0.

Wilcke, W., \& Amelung, W. (2000). Persistent organic pollutants in native grassland soils along a climosequence in North America. Soil Science American Journal, 64, 2140-2148.

Wilczyńska-Michalik, W., \& Michalik, M. (2017). Air pollution in Krakow - a glance into the future from a historical perspective. Acta Geobalcanica, 3-2, 79-82.

Xue, P. P., Carrillo, Y., Pino, V., Minasny, B., \& McBratney, A. B. (2018). Soil Properties Drive Microbial Community Structure in a Large Scale Transect in South Eastern Australia. Scientific Reports, 8, 11725.

Yavitt, J. B., Wright, S. J., \& Wieder, R. K. (2004). Seasonal drought and dry-season irrigation influence leaf-litter nutrients and soil enzymes in a moist, lowland forest in Panama. Austral Ecology, 29, 177-188.

Zhan, X., Wu, W., Zhou, L., Liang, J., \& Jiang, T. (2010). Interactive effect of dissolved organic matter and phenanthrene on soil enzymatic activities. Journal of Environmental Sciences, 22(4), 607-614.

Zhang, X. X., Cheng, S. P., Zhu, C. J., \& Sun, S. L. (2006). Microbial PAH-Degradation in Soil: Degradation Pathways and Contributing Factors. Pedosphere, 16(5), 555-565.

Zhang, Y., Cui, D., Yang, H., \& Kasim, N. (2020). Differences of soil enzyme activities and its influencing factors inder different flooding conditions in Ili Valley, Xinjiang. PeerJ, 8, e8531.

Zhou, Q. X., \& Hua, T. (2004). Bioremediation: A review of applications and problems to be resolved. Progress in Natural Science, 14(11), 937-944.

Zhuang, X., Chen, J., Shim, H., \& Bai, Z. (2007). New advances in plant growth-promoting rhizobacteria for bioremediation. Environment International, 33, 406-413.

Publisher's Note Springer Nature remains neutral with regard to jurisdictional claims in published maps and institutional affiliations. 